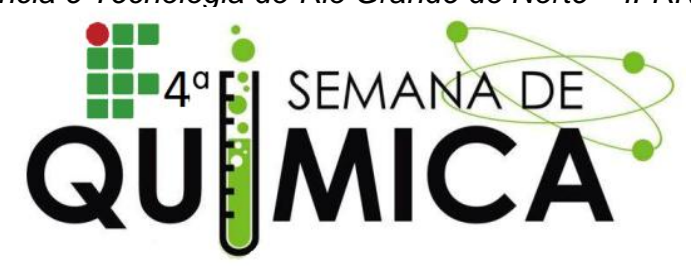

\title{
CINÉTICA QUÍMICA: ATIVIDADE LÚDICA COMO FERRAMENTA PARA O ENSINO E APRENDIZAGEM
}

*LIMA, B. R. D. (IFRN); COSTA, T. M. M. (IFRN); REINALDO, S. M. A. S. (EEPAD); BERTINI, L. M. (IFRN); ALVES, L. A. (IFRN); FERNANDES, P. R. N. (IFRN)

Palavras Chave: aprendizagem, conhecimento, química.

\section{INTRODUÇÃO}

Os jogos são um importante recurso para as aulas de química, no sentido de servir como um reabilitador da aprendizagem mediante a experiência e a atividade dos estudantes. Segundo Miranda (2001), mediante o jogo didático, vários objetivos podem ser atingidos, relacionados à cognição (desenvolvimento da inteligência e da personalidade, fundamentais para a construção de conhecimentos); afeição (desenvolvimento da sensibilidade e da estima e atuação no sentido de estreitar laços de amizade $\mathrm{e}$ afetividade); socialização (simulação de vida em grupo); motivação (envolvimento da ação, do desfio e mobilização da curiosidade) e criatividade.

Diante disso, foi criado o jogo "Perguntas e Respostas" com o objetivo de melhorar o entendimento do conteúdo de Cinética Química. O jogo citado, foi confeccionado e aguarda a explanação do conteúdo central do mesmo, para ser aplicado.

\section{METODOLOGIA}

O jogo titulado "Perguntas e Respostas" é composto por cartas contendo perguntas e respostas referentes ao conteúdo de Cinética Química e uma carta contendo o QUÍ-MICO, que será a carta que eliminará um jogador. $O$ jogo tem como objetivo associar as perguntas e respostas, diversificando e tornando divertido o estudo do conteúdo. O número de participantes vai de 3 a 4. A regra é simples: embaralhar todas as cartas deixando-as viradas para baixo. Cada participante deve retirar uma carta até que todas terminem (um jogador ficará com uma carta a mais).

Cada membro deverá colocar sobre a mesa os pares que conseguiu formar com suas cartas, por exemplo: uma pergunta com a respectiva resposta. A seguir quem retirou a última carta da mesa mostrará o verso das cartas para o seu companheiro da esquerda para que ele retire uma delas. Se formar um par deverá colocá-lo sobre a mesa, caso não forme um par deverá ficar com as cartas que serão mostradas ao próximo colega para que esse retire uma carta. E assim o jogo deverá continuar até formarem todos os pares. O aluno que ficar com o QUÍ-MICO perde o jogo e deverá cumprir uma tarefa combinada pelos companheiros. Se for necessário o professor poderá interromper o jogo e ajudar os participantes sobre as dificuldades e dúvidas do referido assunto.

\section{RESULTADOS ESPERADOS}

Pretende-se com a aplicação do jogo melhorar o entendimento do conteúdo de Cinética Química, melhorar a relação ensinoaprendizagem, além de funcionar como ferramenta auxiliadora para o professor.

Almeja-se ao fim deste trabalho identificar a eficácia do uso de jogos didáticos para o ensino de Química.

\section{REFERÊNCIAS}

MIRANDA, S. No Fascínio do jogo, a alegria de aprender. In: Ciência Hoje, v.28, 2001 p. 64-66

\section{AGRADECIMENTOS}
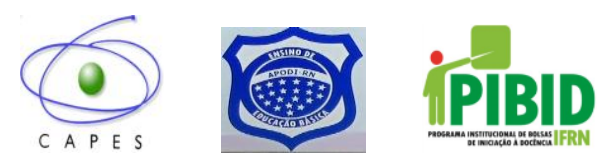